\title{
Türkiye'de Yurt İçi Üretici ve Tüketici Fiyatları Üzerindeki Döviz Kuru Geçişkenliğinin İncelenmesi
}

\section{Investigation of the Exchange Rate Pass-through Effect on Domestic Producer and Consumer Prices in Turkey}

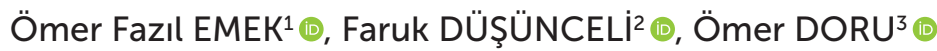

\begin{abstract}
Öz
Bu çalışmanın amacı, Türkiye ekonomisinin 2005:1-2020:4 dönemi için nominal döviz kuru değişimlerinin fiyat düzeyleri (TÜFE, ÜFE) üzerindeki etkisini ekonometrik yöntemlerle analiz etmektedir. Bunun için 2005-2020 yılları arası Türkiye'nin çeyreklik enflasyon, döviz kuru, sanayi üretimi ve ithalat birim değer endeksi arasındaki kısa ve uzun dönemli eş bütünleşme ilişkileri analiz edilmiştir. Enflasyon oranını temsilen tüketici fiyat endeksi (tüfe) ve üretici fiyat endeksi (üfe) değişkenleri baz alınarak iki farklı model oluşturulmuştur. ARDL sınır testi sonuçlarına göre uzun dönemde ilk modelde, sanayi üretim endeksi, nominal döviz kuru ve ithalat birim değer endeksindeki \%1'lik bir artış sırasıyla tüketici fiyatlarında \%0,37, \%0,69 ve \%0,58'lik artışa neden olmaktadır. Diğer modelde ise nominal döviz kuru ve ithalat birim değer endeksindeki \%1'lik bir artış sırasıyla üretici fiyatlarında $\% 0,82$ ve \%0,73'lük artışa yol açmaktadır. Elde edilen bu bulgulara göre Türkiye'de yurtiçi tüketici fiyatları üzerinde döviz kuru, sanayi üretimi ve ithal fiyatların; yurt içi üretici fiyatları üzerinde ise döviz kuru ve ithal fiyatların anlamlı ve etkili olduğu tespit edilmiştir. Yine bu bulgular, döviz kurlarından hem yurt içi üretici hem de yurt içi tüketici fiyatlarına geçişkenliğin varlığını göstermektedir. Çalışmanın sonuçları konu hakkında yapılan literatüre paralellik göstermektedir.
\end{abstract}

Anahtar kelimeler: Enflasyon, İthalat fiyatları, Döviz kuru geçişkenliği

JEL Sınıflaması: B22, C22, E31

\section{ABSTRACT}

This study analyzes the effect of nominal exchange rate changes in the 2005:1-2020:4 period, applying econometric methods to examine Turkey's economy at the level of consumer price index (CPI) and producer price index (PPI). For this purpose, shortand long-term co-integration relationships between Turkey's inflation, exchange rate, industrial production, and import unit value indices in the period 2005-2020 were investigated. Two different models were created based on CPI and PPI variables as representative of the inflation rate. We used the auto-regressive distributed lag (ARDL)boundary test to determine the short and

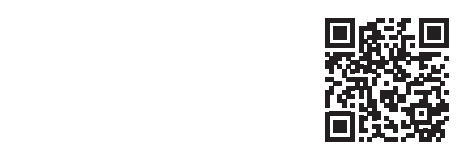

DOI: 10.26650/ISTJECON2021-915644

'Dr. Öğr. Üyesi, Mardin Artuklu Üniversitesi, Nusaybin Meslek Yüksekokulu, Mardin, Türkiye ${ }^{2}$ Dr. Öğr. Üyesi, Mardin Artuklu Üniversitesi, İktisadi ve İdari Bilimler Fakültesi, Mardin, Türkiye

${ }^{3}$ Dr. Öğr. Üyesi, Mardin Artuklu Üniversitesi, İktisadi ve İdari Bilimler Fakültesi, Mardin, Türkiye

ORCID: Ö.F.E. 0000-0003-4429-8892;

F.D. 0000-0002-2368-7963;

Ö.D. 0000-0001-8119-4908

\section{Sorumlu yazar/Corresponding author:} Ömer Fazıl EMEK, Mardin Artuklu Üniversitesi, Nusaybin Meslek Yüksekokulu, Dış Ticaret Bölümü, Mardin Artuklu Üniversitesi Yabancı Diller Yüksekokulu Savurkapı mah. Meydanbaşı, Mardin, Türkiye E-posta/E-mail: omerfazilemek@artuklu.edu.tr, ofemek@gmail.com

\section{Başvuru/Submitted: 15.04 .2021}

Revizyon Talebi/Revision Requested: 26.04.2021

Son Revizyon/Last Revision Received: 05.05.2021

Kabul/Accepted: 06.05.2021

Atıf/Citation: Emek, O.F., Dusunceli, F., \& Doru, O. (2021). Türkiye'de yurt içi üretici ve tüketici fiyatları üzerindeki döviz kuru geçişkenliğinin incelenmesi. İstanbul Iktisat Dergisi - Istanbul Journal of Economics, 71(1), 163-190. https://doi.org/10.26650/ISTJECON2021-915644 
long term relationship between variables. According to ARDL boundary test results, in the CPI model, a $1 \%$ increase in the industrial production index, nominal exchange rate, and import unit value index causes $0,37 \%, 0,69 \%$, and $0,58 \%$ increases in consumer prices, respectively. In the PPI model, a $1 \%$ increase in the nominal exchange rate and import unit value index causes $0,82 \%$ and $0,73 \%$ increases in producer prices, respectively. These findings indicate that exchange rate, industrial production, and import price have an impact on domestic consumer prices in Turkey. Similarly, it appears that exchange rate and import prices affect domestic producer prices, also demonstrating the existence of an exchange rate pass-through effect on both domestic producer and domestic consumer prices. The results of the study are in congruence with previous literature on the subject.

Keywords: Inflation, ;mport prices, Exchange rate pass-through

JEL Classification: B22, C22, E31

\section{EXTENDED ABSTRACT}

The effect of exchange rate changes on national economic indicators has been an important topic of discussion in economics literature since the 1990s when trends in globalization intensified. It can be said that the most significant effect of fluctuations in the nominal exchange rate on a national, economy is experienced at the level of prices. Goldberg and Knetter (1997), define the effect of exchange rate transitions on prices as the percentage of change caused by a $1 \%$ alteration in exchange rates on the prices of imported goods in national currency. Menon (1995) explains this exchange rate transition effect as the degree to which the change in the exchange rate is reflected in the cost of goods subject to international trade (import/ export) in terms of the target country's currency. This degree of impact reveals different definitions. When a change in the exchange rate causes a price change reflecting the same rate, it is called the full transition effect, whereas a price effect that is relatively lower than the change in the exchange rate is called the partial transition effect. When exchange rate changes do not affect national prices, it is understood that no transition effect has taken place (Arı, 2010).

The effect of fluctuations in exchange rates on domestic producer and consumer prices has a prominent place in the literature. This topic is extremely popular in Turkey, and empirical studies on this subject are consistently pursued and renewed, as it is important to understand to what extent changes in exchange rates are determinants of price increases. In almost all empirical studies concerning Turkey, an exchange rate pass-through effect on domestic prices is concluded. Considering the circumstances, such as the fact that inflation figures fell to single digits after 2001 
and the adoption of the inflation targeting regime after 2006, it is understood that this transition has partially decreased compared to previous periods, but continues to be a determining factor of prices. In addition, when evaluated by separating producer and consumer prices, it is generally assumed that increases in exchange rates affect producer prices more strongly than consumer prices, due to Turkey's high degree of dependence on imported inputs to facilitate production, echoing other studies in international literature. Raised exchange rates put pressure on the cost of products directly through imported goods.

This study aims to analyze the effect of changes in the nominal exchange rate for the 2005:1-2020:4 period, applying econometric methods to examine Turkey's economy at the level of consumer price index (CPI) and producer price index (PPI). For this purpose, in the period 2005-2020, short- and long-term cointegration relationships between Turkey's inflation, exchange rate, industrial production, and import unit value indices are analyzed. Two different models were created based on inflation, using CPI and PPI as the dependent variables representative of the inflation rate. According to the ARDL boundary test results, in the CPI model, the nominal exchange rate and import unit index coefficients are statistically significant at $1 \%$ and the industrial production index coefficient at $5 \%$. Additionally, a $1 \%$ increase in the industrial production index results in a $0,37 \%$ increase in $\mathrm{CPI}$, a $1 \%$ increase in the nominal exchange rate results in a $0,69 \%$ increase in $\mathrm{CPI}$, and a $1 \%$ increase in the import unit value index results in a $0,58 \%$ increase in CPI. In the PPI model, nominal exchange rate and import unit index variables are statistically significant at a $1 \%$ level, whereas the $5 \%$ level of the industrial production index variable is not statistically significant. Furthermore, a $1 \%$ increase in the nominal exchange rate causes an increase of $0,82 \%$ in the PPI, and a $1 \%$ increase in the import unit value index causes an increase of $0,73 \%$ in the PPI. These findings indicate that exchange rate, industrial production, and import price have an impact on domestic consumer prices in Turkey. Similarly, it appears that exchange rate and import prices affect domestic producer prices, also demonstrating the existence of an exchange rate pass-through effect on both domestic producer and domestic consumer prices. The results of the study are in congruence with previous literature on the subject. 


\section{Giriş}

Küreselleşme ve neo-liberal politikaların bir sonucu olarak son 40 yıllık süreçte ticari ve finansal serbestleşmenin yoğunlaşarak devam ettiği görülmektedir. Yaşanan bu gelişmeler birçok alanda sosyo-ekonomik bir dönüşüme aracılık etmiştir (Dikkaya ve Özyakışır, 2006). Ekonomik sistemde yaşanan en önemli dönüşümlerin döviz kuru sistemleri ve para politikalarında yaşandığını söylemek mümkündür. Bu nedenle bu dönemde döviz kuru politikaları ve enflasyon hedeflemeleri, iktisat literatürünün olduğu gibi politika yapıcıların gündeminde de yer almıştır. Özellikle 1990 'lı yıllarda sabit kur sistemine dayalı gelişmekte olan ekonomiler (Meksika, Tayland, Endonezya, Rusya, Kore, Brezilya, Arjantin ve Türkiye) ciddi finansal krizlerle baş başa kaldılar (Fischer, 2001). Bu krizlerin ekonomik göstergeler üzerindeki en ciddi etkisinin enflasyon göstergesi üzerinde yaşandığı görülmüştür. Fischer (2001), ara rejimlerin sürdürülemez olduğunu "imkânsız üçleme hipotezi" ile açıklamaktadır. Hipoteze göre bir ekonomideki serbest sermaye akımları, bağımsız para politikası ve sabit döviz kuru aynı anda sürdürülebilir politikalar olmayacaktır. Bu noktada döviz kurlarındaki değişimlerin yurtiçi fiyatları üzerindeki etkileme derecesi diye tanımlanan döviz kuru geçişkenliği (DKG), literatürde önemli bir tartışma konusu olarak yer edinmiştir.

Ulusal fiyat düzeyinin nominal kur şoklarına duyarlılığını ifade eden döviz kuru geçiş etkisinin belirlenmesi, politika yapıcıların enflasyon öngörüsünde önemli rol oynayacaktır. Bunun yanında yüksek enflasyon şoklarına yönelik uygulanacak para politikalarının tespiti için de belirleyici bir kanıt olacaktır (Arı, 2010). Türkiye ekonomisi, gelişmekte olan birçok ülke gibi 1990'lı yıllarda yüksek enflasyon olgusuyla karşı karşıya kalmıştır. Bu dönemde yaşanan yüksek döviz kuru şokları önemli bir faktör olduğu gibi uygulanan para ve döviz kuru politikaları da belirleyici unsurlar olmuştur. 2003 yılından sonra ise Türkiye ekonomisinde istikrarlı para ve döviz kuru politikaları enflasyon üzerinde azaltıcı etkilere sahip olmuştur. Ancak son yıllarda hem bölgesel hem de küresel düzeyde yaşanan siyasi krizler, döviz kuru şoklarını ve beraberinde yüksek enflasyon sorununu getirmiştir. Bu çalışmanın amacı, Türkiye ekonomisinin 2005:1-2020:4 dönemi için nominal döviz kuru değişimlerinin fiyat düzeyleri (TÜFE, ÜFE) üzerindeki etkisini 
ekonometrik yöntemlerle analiz etmektedir. Çalışmanın giriş bölümünden sonra teorik ve ampirik literatür bilgisine daha sonra çalışmanın veri seti, yöntem ve bulgular kısmına son olarak ampirik bulguların değerlendirildiği sonuç kısmına yer verilecektir.

\section{Teorik Çerçeve}

Döviz kuru değişimlerinin ulusal ekonomik göstergeler üzerindeki etkisi küreselleşme eğilimlerinin yoğunlaştığı 1990'lı yıllardan itibaren iktisat literatüründe önemli bir tartışma alanı olmuştur. Nominal kurda meydana gelen dalgalanmaların ulusal ekonomi üzerindeki en önemli etkisinin fiyat düzeyinde yaşandığını söylemek mümkündür. Döviz kurunun fiyatlara geçiş etkisini Goldberg ve Knetter (1997), döviz kurlarında yaşanan yüzde \%1'lik değişimin ithal malların fiyatlarında ulusal para cinsinden meydana getirdiği yüzde değişim olarak tanımlamaktadır. Menon (1995) ise döviz kuru geçiş etkisini, döviz kurunda yaşanan değişimin hedef ülke parası cinsinden uluslararası ticarete konu olan malların (ithalat, ihracat) fiyatlarına yansıtılma derecesi olarak açıklamaktadır. Bu noktada etkinin derecesi farklı tanımlamaları ortaya çıkarmaktadır. Kurda yaşanan değişimin aynı oranda fiyat değişimine neden olması "tam geçiş etkisi," fiyat etkisinin kur değişiminden nisbi olarak daha düşük olması "kısmi geçiş etkisi" olarak ifade edilir. Kur değişiminin ulusal fiyatları değiştirmemesi durumunda ise geçiş etkisinin olmadığı şeklinde anlaşılır (Arı, 2010).

Hyder ve Shah (2004), döviz kurunun doğrudan ve dolaylı olmak üzere iki yoldan enflasyon üzerinde etkili olduğunu belirtmektedirler. Öncelikle dışa açık ekonomilerde yaşanan döviz kuru değişimlerinin, ulusal para cinsinden ithal nihai ve ara mallarının fiyatları üzerindeki etkisi doğrudan etkiyi göstermektedir. İthal nihai mal fiyatında yaşanan değişim fiyat düzeyi üzerinde (TÜFE) doğrudan etkilidir. İthal ara malları fiyatında yaşanan değişim ise üretim maliyetleri dolayısıyla üretilecek ürünün fiyatı (ÜFE) üzerinde etkili olacaktır. Dolaylı etki ise kur değişiminin ithal ikame malları ve ihracat mallarına olan talep miktarı üzerindeki etkiyi ifade etmektedir. Kur değişimlerinin ithal mal fiyatları üzerindeki etkisi ithal ikame mal talebi üzerinde dolayısıyla fiyat düzeyi üzerinde dolaylı etkiye sahiptir. 
Aynı zamanda ihracat ürünlerine olan talebin artması bu malların fiyat düzeyinde de artış meydana getirecektir.

Son dönemlerdede yapılan ampirik literatürün önemli bir kısmında, fiyatların döviz kuru hareketlerini tam olarak yansıtmadığını, eksik veya kısmi geçiş etkisinden bahsetmenin mümkün olduğunu ortaya koymaktadır. Bu olguyu LópezVillavicencio ve Mignon (2017) iki yaklaşımla açıklamaktadırlar. Bunlar eksik geçiş etkisinin kısa vadede fiyatlarda tepkisizliğe yol açan nominal katılıklardan geldiğini belirten makroekonomik yaklaşım ve firmaların artan piyasa fiyatlandırma davranışına bağlayan mikroekonomik yaklaşımdır. Kısmi geçiş etkisinin bir diğer nedenin firmaların pazara dayalı fiyatlandırma stratejilerinin olduğu söylenebilir (Betts ve Devereux, 2000; Flamini, 2007). Buna göre dış ticaret firmaları, pazar kaybetme riskini göze almayarak nominal kur değişimlerini fiyatlara eksik yansıtırlar veya yansıtmazlar. Bu durumu kâr marjlarını azaltarak finanse etmektedirler. Bunun yanında Taylor (2000), uygulanan para politikasının geçiş etkisi derecesinde etkili olduğunu belirtmektedir. Buna göre istikrarlı ve öngörülebilir bir para politikası ortamı, nominal fiyat şokları ve döviz kuru dalgalanmalarının tetiklenmesinde azaltılmış bir rol oynar. Taylor'un bu yaklaşımında; döviz kurlarının fiyatlara düşük olarak yansıması enflasyonun düşük olmasıyla ilgilidir. Enflasyon oranı düşük olan ülkelerde geçiş etkisinin nihai malların fiyatlarına yansıması daha düşüktür (Campa ve Goldberg, 2005).

\section{Literatür Özeti}

\subsection{Türkiye Üzerine Yapılan Ampirik Çalışmalar}

Döviz kurlarındaki dalgalanmaların yurt içi üretici ve tüketici fiyatları üzerindeki etkisi gerek yerli gerekse yabancı literatürde geniş bir yer tutmaktadır. Konunun özellikle Türkiye'de ilgi çekmesi ve buna yönelik ampirik çalışmaların sürekli yenilenmesinin nedeni, fiyatlarda meydana gelen yükselişlerde döviz kurlarının ne derece belirleyici olduğunun anlaşılması içindir. Türkiye için yapılan ampirik çalışmaların hemen hemen tamamında döviz kurlarından yurt içi fiyatlara doğru bir geçişkenliğin olduğu kanaatine varılmıştır. Bu geçişkenliğin 2001 yılı sonrası 
enflasyon rakamlarının tek haneye düşmesi ve 2006 yılı sonrası enflasyon hedeflemesi rejiminin benimsenmesi gibi süreçler dikkate alındığında daha önceki dönemlere göre kısmen düştüğü ancak yine de fiyatlarda belirleyici unsur olmaya devam ettiği anlaşılmaktadır. Ayrıca üretici ve tüketici fiyatları ayırımı yapılarak değerlendirildiğinde, döviz kurlarındaki yükselişlerin üretici fiyatlarını tüketici fiyatlarından daha çok etkilediği çalışmaların çoğundan çıkarılması gereken genel bir kanaattir. Bunun nedenin de uluslararası literatürdeki çalışmalara benzer bir şekilde Türkiye'nin ithalata ve ithal girdilere olan yüksek dereceli bağımlılığıdır. Artan döviz kurları doğrudan ithal mallar aracılığıyla ürünlerin maliyetine baskı yapmaktadır. Yapılan bu değerlendirmeler aşağıda özetleri sunulan çalışmalara dayanmaktadır.

Kaya (2018), Türkiye'de 2003-2016 yılları arası döviz kurlarının yurt içi üretici fiyatları üzerindeki geçiş etkisini incelemek amacıyla yaptığı bir çalışmadır. VAR analizi ile elde edilen bulgulara göre döviz kurlarından enflasyona geçiş etkisinin yüzde 15 olduğu belirlenmiştir. Bu oran 1990'lı yıllara nazaran daha az bir seviyede olsa da enflasyon oranlarındaki belirgin etkisini devam ettirmektedir. Dışsal bir değişken olarak alınan petrol fiyatları ise gerek doğrudan gerekse döviz kurları kanalıyla enflasyonda yüzde 28'lik bir geçiş etkisine sahiptir. Türkiye'nin 2001 krizi sonrası yeni para politikası rejimi tercihi neticesinde döviz kurlarından enflasyona geçişkenlik etkisi kısmen azalma göstermiştir.

Leigh ve Marco Rossi (2002), Türkiye'de döviz kuru ile yurt içi fiyatlar arasında güçlü bir ilişkinin olduğu varsayımından yola çıkarak 1994-2002 yıları arası döviz kurundan yurt içi tüketici ve toptan eşya fiyatları üzerindeki geçişkenliği incelemek amacıyla yaptıkları bir çalışmadır. VAR analizi ile elde edilen bulgulara göre döviz kurundan tüketici fiyatlarına geçiş etkisi yüksek ve hızlıdır. Ilk dört ayda yoğunlaşıp 11. aya kadar sürmektedir. Bu etkiye neden olan unsurların yüksek dereceli dolarizasyon, yüksek enflasyonist beklentileri ve develüasyon olduğu belirtilmiştir. Ayrıca Türkiye'nin oligopolist endüstriyel yapısından dolayı toptancıların dış şokları hızı bir şekilde perakendecilere aktarması geçişkenliği hızlandıran bir diğer önemli etkendir. Döviz kurlarından toptan fiyatlara doğru geçişkenlik ise tüketici fiyatlarına göre daha belirgindir. Çünkü toptan eşya fiyat endeksi ticari malların yaklaşık yüzde 
70'ini içermektedir. Bu sonuçlar, diğer gelişmekte olan ülkelerle kıyaslandığında geçişkenliğin daha hızlı ve daha kısa sürede gerçekleştiğini göstermektedir.

Kara ve Öğünç (2012), Türkiye'de 2002-2011 yılları arası döviz kurları ile ithalat fiyatlarının çekirdek fiyatlar üzerindeki geçişkenlik etkisini incelemişlerdir. VAR analizi ile elde edilen bulgulara göre her iki değişkeninde bir yıl içerisindeki fiyatlara geçişkenliği yüzde 15 civarındadır. Bu sonuç, ithalat fiyatlarındaki değişimlerin çekirdek fiyatlar üzerindeki etkisinin döviz kurlarındaki değişim kadar önemli olduğunu göstermektedir. Ayrıca geçişkenlik düzeyi yıllara göre azalmaktadır. Bunun nedeni olarak 2001 krizi sonrası dalgalı döviz kurunun benimsenmesi ve enflasyon seviyelerindeki düşüş gösterilmiştir.

Altıntaş (2014), Türkiye'de 1987-2011 yılları arası döviz kurlarının enflasyon üzerindeki geçiş etkisini belirlemek amacıyla yaptığı bu çalışmada üç ayrı model kurulmuştur. ARDL yöntemi ile elde edilen bulgulara göre döviz kurlarında meydana gelen yüzde 1 'lik bir artışın enflasyonu da sırasıyla yüzde $0,72,0,85$ ve 0,91 artırdığı görülmüştür. Döviz kurlarından yurt içi fiyatlara doğru geçiş etkisi kısmi ancak yine de yüksek seviyelerdedir. Bu durumun nedenleri arasında 1994 ve 2001 yıllarında yaşanan parasal krizler, üretimde sermaye mallarına dolayısıyla ithal girdilere bağımlılık ve giderek artmakta olan dışa açılma oranları gösterilmiştir.

Bayat, Özcan ve Taş (2015), Türkiye'de 2003-2013 yılları arası reel döviz kurları ile tüketici fiyatları arasında geçiş etkisinin olup olmadığını belirlemek amacıyla yaptığı bir çalışmadır. Nedensellik analizinden elde edilen bulgulara göre reel döviz kurundan tüketici fiyatlarına bir nedenselliğin olmadığı ancak tüketici fiyat endeksinden reel döviz kuruna doğru tek yönlü bir nedenselliğin varlığı tespit edilmiştir. Yani döviz kurundan yurt içi fiyatlara doğru bir geçişkenliğin olduğu görülmemiştir. Bunun nedeni olarak Türkiye'nin 2001 yılı sonrası dalgalı kur ve 2006 yılı sonrası ise enflasyon hedeflemesi rejimlerini benimsemesi gösterilmiştir.

Özdamar (2015), Türkiye'de 2006-2015 yılları arası döviz kurundan yurt içi üretici fiyatlarına geçiş etkisini incelemek amacıyla yaptığı bir çalışmadır. ARDL sınır testi ile elde edilen bulgulara göre uzun dönemde nominal döviz kurları, dünya 
petrol fiyatları ve sanayi üretimi endeksinde meydana gelen yüzde 1 'lik artış üretici fiyatlarından kaynaklanan enflasyonu sırasıyla yüzde 0,13, 0,05 ve 0,22 dolaylarında artırmaktadır. Bu sonuçlar, sanayi üretim endeksinin enflasyon üzerinde diğer değişkenlere nazaran daha etkili olduğunu göstermektedir. İncelen dönem aralığında enflasyonun kısmen düşük seviyelerde olduğu göz önünde bulundurulursa döviz kurlarından enflasyona geçişkenliğin de düşük kaldığı görülmektedir.

Türk ve Çetinkaya (2015), Türkiye'de 1987-2013 yılları arası döviz kurlarından yurt içi tüketici fiyatları üzerindeki geçiş etkisini incelemek amacıyla yaptığı bir çalışmadır. Bunun için Granger nedensellik testinden elde edilen bulgulara göre döviz kurundan tüketici fiyat endeksi ve toptan eşya fiyat endeksine doğru tek yönlü bir nedenselliğin varlığı tespit edilmiştir. Bu sonuca neden olarak Türkiye'nin ara malı ithalatında dışa bağıı olması ve bu nedenle döviz kurlarındaki hareketliliğin maliyetlere ve tüketici fiyatlarına yansıması gösterilmiştir.

Alptekin, Yılmaz ve Taş (2016), Türkiye'de 2005-2015 yılları arası döviz kurlarının üretici ve tüketici fiyatları üzerindeki geçiş etkisini incelemişlerdir. VAR analizi ile elde edilen bulgulara göre üretici fiyatlarının döviz kurlarından tüketici fiyatlarına göre daha çok etkilendiği, bu durumda geçiş etkisinin üretici fiyatlarında daha fazla görüldüğü tespit edilmiştir. Bu bulguların temel dayanağının Türkiye'de 2001 yılı ve sonrası enflasyon raklamlarının tek haneye düşmesi ve dalgalı döviz sistemine geçmesi olarak belirtilmiştir.

Tümtürk (2017), Türkiye'de 1994-2016 yılları arası döviz kurlarında meydana gelen şokların yurt içi üretici fiyatları üzerindeki etkisini incelemek amacıyla yaptığı bir çalışmadır. Bunun için açık enflasyon hedeflemesinin uygulanmaya koyulduğu dönem baz alınarak dönemler arası karşılaştırmalı değerlendirilme yapılmışırı. Klasik en küçük kareler (E.K.K.) yöntemi kullanılarak elde edilen bulgulara göre enflasyon hedeflemesine geçilmeden önce döviz kurundan yurt içi üretici fiyatlarına geçiş katsayısı 0,64, enflasyon hedeflemesine geçildikten sonra ise 0,28 olarak hesaplamıştır. 2006 yılına kadar Türkiye'de enflasyon ataletinin olduğu ancak enflasyon hedeflemesi ile birlikte bu atalette kırılma yaşandığı, bu nedenle geçiş etkisi katsayısında bir azalma meydana geldiği ifade edilmektedir. 
Akdemir ve Özçelik (2018), Türkiye'de 2003-2017 yılları arası döviz kurlarının imalat sanayi ve tüketici fiyatları üzerindeki geçiş etkisini belirlemek amacıyla yaptıkları çalışmadadır. Yapısal VAR (SVAR) yöntemi ile elde edilen bulgulara göre döviz kurlarının her iki değişkeni de etkilediği ancak sanayi üretiminin yurt içi fiyatlara göre daha fazla etkilendiği belirlenmiştir. Bu sonuçlar döviz kurundan tüketici fiyatlarına doğru geçişkenliğin kısmi olduğunu, üretimde kullanılan ithal girdilerin ve ithalata olan bağımlılığın azaltılması gerektiğini göstermektedir.

Karaoğlu ve Kılıçkaplan (2018), Türkiye'de 2004-2018 yılları arası döviz kurlarının üretici ve tüketici fiyatları üzerindeki geçiş etkisini enflasyon düzeyine bağlı olup olmama durumuna göre incelemişlerdir. Bunun için doğrusal olmayan modellerden biri olan yumuşak geçişli regresyon yöntemi kullanılmıştır. Elde edilen bugulara göre yüzde 7'ye kadar olan enflasyon düzeyi döviz kurlarından tüketici fiyatlarına geçişkenliği yüzde 7,6; enflasyonun yüzde 7'yi aşması ile geçişkenliği yüzde 11,6'ya çıkarmaktadır. Benzer şekilde yüzde 4,4'e kadar olan enflasyon düzeyi döviz kurlarından üretici fiyatlarına geçişkenliği yüzde 24,1; enflasyonun yüzde 4,4'den sonra artışı ise geçişkenliği yüzde 37,5'e çıkarmaktadır. Bu bulgular, döviz kurlarındaki geçiş etkisinin tüketici fiyatlarına karşılık üretici fiyatlarında daha fazla olduğunu göstermektedir. Bunun nedeninin Türkiye'de üretimde kullanılan ithal ara malı oranının yüksek seviyelerinden kaynaklandığı belirtilmektedir.

Koç (2018), Türkiye'de 1990-2017 yılları arası döviz kuru ile enflasyon arasında doğrusal olmayan bir geçiş etkisinin olup olmadığını incelemek amacıyla yaptığı bir çalışmadır. KSS eş bütünleşme testi sonuçlarına göre döviz kurundan enflasyona doğru geçiş etkisinin olmadığı tespit edilmiştir. Bu durumun nedeni olarak 1990'lı yıllarda enflasyonu tetikleyen unsurun yüksek kamu açıklarının merkez bankası kaynakları kullanılarak kapatılmaya çalışıması, 2002 yılından sonra ise enflasyon hedeflemesi rejiminin uygulanması gösterilmiştir.

Göktaş (2019), Türkiye'de 2003-2018 yılları arası nominal döviz kurları ile tüketici fiyatları arasında asimetrik bir ilişkinin olup olmadığını belirmek amacıyla yaptığı bir çalışmadır. Doğrusal olmayan sınır testi (NARDL) yaklaşımı ile elde edilen analiz bulgularına göre döviz kurlarında meydana gelen yüzde 1 'lik artış, tüketici fiyatlarının 
yüzde 0,24 artmasına; döviz kurlarında meydana gelen yüzde 1'lik azalış ise tüketici fiyatlarının bu kez yüzde 0,17 artmasına neden olmaktadır. Yani döviz kurlarında yukarı yönlü hareketin tüketici fiyatları üzerindeki geçiş etkisinin, aşağı yönlü hareketinin tüketici fiyatları üzerindeki geçiş etkisinden daha güçlü olduğu görülmüştür. Bu durumun nedenin belirtilen tarihler arasında Türkiye'nin ara malı ithalatının toplam ithalat içerisindeki payının yüzde 70 oranından fazla olması, döviz kurlarında meydana gelen ufak bir değişikliğin anında maliyet kanalı aracılığıyla yurt içi fiyatlara yansımasından kaynaklandığı belirtilmiştir.

Baş ve Kara (2020), gelişmekte olan piyasalar içerisinde yer alan Türkiye'de 2010-2020 yılları arası döviz kurlarının yurt içi fiyatlar üzerindeki geçiş etkisini belirlemek amacıyla yaptıkları bir çalışmadır. ARDL yöntemi ile elde edilen bulgulara göre uzun dönemde döviz kurları, ithalat fiyat endeksi ve gayri safi yurt içi hasılada meydana gelen yüzde 1 'lik artış enflasyonu sırasıyla yüzde 0,61, 0,46 ve 0,51 dolaylarında artırmaktadır. Döviz kurlarından yurt içi fiyatlara geçişkenliğin önemli bir seviyede olmasının nedenin Türkiye'nin yoğun dışa açık bir ekonomiye sahip olmasından kaynaklandığı belirtilmiştir.

Güler (2020), Türkiye'de 2006-2019 yılları arası efektif döviz kurlarının yurt içi tüketici, yurt içi üretici ve ithalat fiyatları üzerindeki etkisini belirlemek amacıyla yaptığı bir çalışmadır. Bunun için üç ayrı model oluşturulmuştur. ARDL sınır testi yaklaşımından elde edilen bulgulara göre her üç modelde de döviz kurları katsayı büyüklügü itibariyle sırasıyla en fazla ithalat fiyatları, yurt içi üretici ve yurt içi tüketici fiyatlarını etkilemektedir. Benzer şekilde petrol fiyatlarında ve sanayi üretim endeksinde gerçekleşen artışlar her üç fiyat türünü de artırmaktadır. Bu sonuçlar, genel olarak kur baskısının maliyetler aracılığıyla en çok üreticilere yansıdığını göstermektedir.

\subsection{Yabancı Ülke ve Ülke Grupları Üzerine Yapılan Ampirik Çalışmalar}

Döviz kurlarından genel itibariyle yurt içi tüketici, yurt içi üretici ve ithalat fiyat endekslerine geçişkenliğini konu edinen çeşitli ülke ve ülke grupları üzerine yapılan araştırmaların -Türkiye üzerine yapılan çalışmalarda olduğu gibi- hemen hemen 
tamamında geçişkenliğin varlı̆̆ belirlenmiştir. Ancak bu geçişkenliğin derecesi ülke veya ülke gruplarının dönem aralıklarına ve ekonomik koşullarına göre değişmektedir. Enflasyon oranlarının, döviz kurlarındaki dalgalanmaların, dolarizasyonun, ithal girdi oranlarının, dışa açıklık ve ithalata açıklık seviyesinin yüksek olduğu dönemlerde geçişkenliğin arttığı, benzer şekilde enflasyon hedeflemesi rejimine geçilmesi ile birlikte bu geçişkenliğin azaldığı çalışmalardan elde edilen genel bulgulardır. Ayrıca döviz kurlarından en fazla etkilenen fiyat endekslerinin sırasıly ithalat fiyatları, yurt içi üretici ve yurt içi tüketici fiyatlarının olduğu görülmektedir. Yapılan bu değerlendirmeler aşağıda özetleri sunulan çalışmalara dayanmaktadır.

Hyder ve Shah (2004), 1988-2003 yılları arası Pakistan'ın döviz kurlarından yurt içi toptan eşya ve tüketici fiyatlarına geçişkenliği incelemek amacıyla yaptıkları bir çalışmadır. VAR analizi ile elde edilen bulgulara göre toptan eşya fiyatlarına geçişkenlik tüketici fiyatlarına göre daha yüksek ancak genel olarak her ikisinde de düşük seviyelerdedir. Geçişkenliğin etkisi 12 aya kadar yayılmasına rağmen en fazla ilk 4 ayda hissedilmektedir. 1988-1997 yılları arası enflasyon oranlarının yüksek olduğu dönemdeki geçişkenliğin, 1997 yılından sonra enflasyon oranlarının kısmen düştüğü dönemlere göre daha güçlü hissedildiği belirtilmiştir.

Campa ve Goldberg (2005), 23 OECD ülkesi için 1975-2003 yılları arası döviz kurlarından ithalat fiyatlarına geçişkenliğin etkisini incelemek amacıyla yaptıkları bir çalışmadır. Panel zaman serilerinden oluşan veriler kullanılarak elde edilen bulgulara göre ithalat fiyatları kısa vadede döviz kurlarındaki dalgalanmaların yüzde 46, uzun vadede ise yüzde $65^{\prime} \mathrm{i}$ ile açıklanmaktadır. ABD için döviz kuru geçişkenliği oranları kısa vadede yüzde 23, uzun vadede ise yüzde 42 olarak hesaplanmıştır. Enflasyon ortalamalarının daha düşük ve döviz kurlarındaki dalgalanmaların yumuşak olduğu ülkelerde geçiş oranları azalmaktadır. Ayrıca gıda ürünlerinin geçiş esneklikleri, enerji ve ithal malı ağıllıkı ürünlerine göre kısmi olmuştur.

Campa ve Minguez (2006), Euro bölgesinden oluşan 13 Avrupa Birliği ülkesinin 1989-2001 yılları arası döviz kurlarından Euro bölgesi dışından yapılan ithalat ürünleri fiyatlarına geçişkenliğin etkisini incelemek amacıyla yaptıkları bir çalışmadır. Kısa vadedeki döviz kuru geçişkenlik katsayısı 0,6'dır. Uzun vadede ise 
İlanda, Belçika ve Hollanda için geçişkenlik katsayısı İtalya, Fransa ve İspanya gibi güney ülkelerine göre daha yüksektir. Bu farklılık, her ülkenin Euro bölgesi dışındaki ithalata açıklık derecesine göre değişmektedir. Ancak bu farklılık, ülkeler veya sektörler arasında büyük değildir.

Korhonen ve Wachtel (2006), 1999-2004 yılları arası Bağımsız Devletler Topluluğu (BDP) ülkelerinin gelişmekte olan 20 ülkeyle karşılaştırmalı olarak döviz kurlarından tüketici fiyatlarına doğru geçişkenliğini incelemek amacıyla yaptıkları bir çalışmadır. VAR analizi ile elde edilen bulgulara göre BDP ülkelerindeki döviz kuru geçişkenliği yükselen piyasa ekonomisi ülkelerine kıyasla daha yüksektir. BDP ülkelerinde döviz kurundan yurt içi fiyatlara tam geçişkenlik, 12 aydan daha kısa bir süre içerisinde yansımaktadır. Bu bulguların ortaya çıkmasının BDP ülkelerindeki yüksek dereceli dolarizasyondan ve bazı BDP ülkelerinin yüksek derecede dışa bağımlı olmasından kaynaklandığı ileri sürülmektedir. Ayrıca geçişkenliğin boyutunun enflasyon seviyesinden etkilenebileceği de belirtilmiştir.

Zorzi, Hahn ve Sánchez (2007), 1975-2004 yılları arası Asya, Latin Amerika ve Orta Doğu'dan oluşan 12 yükselen piyasa ekonomisi ve bir grup gelişmiş ülkeler için döviz kurlarından ithalat ve yurt içi fiyatlarına doğru geçişkenliği incelemek amacıyla yaptıkları bir çalışmadır. VAR analizi ile elde edilen bulgulara göre tek haneli enflasyona sahip ülkelerde -özellikle Asya ülkeleri için geçerli olan- gelişmiş ülkelere benzer şekilde geçişkenliğin düşük olduğu, ülkelerin genelinde yine bu geçişkenliğin gelişmiş ülkelere nazaran çok yüksek olmadığı ayrıca ithalat fiyatlarındaki geçişkenliğin tüketici fiyatlarına göre daha yüksek olduğu görülmüştür.

Ito ve Sato (2008), 1996 yılı yaşanan Asya krizi sonrası Endonezya, Kore, Tayland, Filipinler ve Malezya'dan oluşan Doğu Asya ülkelerinin 1994-2006 yılları arası döviz kurlarının yurt içi üretici, yurt içi tüketici ve ithal fiyatları üzerindeki geçişkenliğin etkisini incelemek amacıyla yaptıkları bir çalışmadır. VAR analizi ile elde edilen bulgulara göre geçiş etkisi sırasıyla en fazla ithalat fiyatları, yurt içi üretici ve yurt içi ithalat fiyatları üzerinde etkili olmuştur. Bu geçişkenliğin gerçekleşmesinde krizin oldukça önemli bir payı olduğu görülmektedir. 
Takhtamanova (2010), 1980-2007 yılları arası 14 OECD ülkesinin döviz kurlarındaki değişimlerin yurt içi fiyatlar üzerindeki geçiş etkisini incelemek amacıyla yaptığı bir çalışmadır. Phillips eğrisi modeliyle elde edilen bulgulara göre döviz kurları ithalat fiyatları vasıtasıyla yurt içi fiyatları etkilemektedir. Ancak gerek kısa gerekse uzun dönemde döviz kurundaki geçişkenliğin etkisi zayıflamaktadır. Bu durumun nedenin 1990'lı yıllarda düşük enflasyon seviyesi olduğu belirtilmiştir. Firmalar, 1990'lı yıllardan sonra önceki yıllara göre fiyatlarını daha az sıklıkla güncellemişlerdir.

Frimpong ve Adam (2010), 1990-2009 yılları arası Gana'da döviz kuru geçişkenliğinin tüketici fiyatları üzerindeki etkisini incelemek amacıyla yaptıkları bir çalışmadır. VAR analizi ile elde edilen bulgulara göre geçişkenliğin kısa vadede düşük ancak önemli olduğu ve bunun da merkez bankası tarafından uygulanan sıkı para politikasının etkisiyle meydana geldiği belirtilmiştir.

Delatte ve Villavicencio (2012), dört büyük ekonomi olarak nitelenen Amerika, İngiltere, Almanya ve Japonya'nın 1980-2009 yılları arası döviz kurlarından yurt içi tüketici fiyatlarına doğru geçiş etkisinin olup olmadığını incelemek amacıyla yaptıkları bir çalışmadır. ARDL sınır testi ile elde edilen bulgulara göre Almanya, Amerika ve İngiltere'nin uzun dönemdeki geçişkenlik katsayıları sırasıyla 0,16, 0,14 ve 0,14 'dür. Asimetrik ARDL sonuçlarına göre ise uzun vadede dört ülkede de geçişkenlik katsayıları pozitif işaretledir. Amerika, Japonya, İngiltere ve Almanya'nın geçişkenlik katsayıları sırasıyla 0,38, 0,15, 0,13 ve 0,12'dir. Bu çalışmadaki geçişkenlik katsayıları geçmişte yapılan çalışmalardan elde edilen bulgulara göre daha yüksek çıkmaktadır. Bunun nedenin 1990'lı yıllardan sonra ithal girdi kullanımının yoğun bir şekilde artması ve nihai üretim maliyetlerinin giderek daha fazla döviz kurlarına bağımlı hale gelmesi olarak belirtilmiştir.

Donayre ve Panovska (2016), 2001-2013 yılları arası Meksika ve Kanada'da enflasyon hedeflemesi rejimi sonrası döviz kurlarından farklı fiyat endekslerine geçişkenliği incelemek amacıyla yaptıkları bir çalışmadır. TVAR analizi ile elde edilen bulgulara göre döviz kuru geçişkenliğinin ekonomik büyüme dönemlerinde daha yüksek olduğu görülmekte bunun da firmaların piyasa gücünü kaybetmeden 
kar oranlarını artırabilmeleri ile açıklanmaktadır. Ayrıca Meksika'da uygulamaya konulan enflasyon hedeflemesi rejimi ile döviz kurları geçişkenliğinin azaldığı ancak tamamen ortadan kaldırılmadığı, genel olarak döviz kurlarındaki geçişkenliğin sırasıyla tüketici fiyatları, üretici fiyatları ve ithalat fiyatlarına en az etki gösterdiği tespit edilmiştir.

Sansone ve Justel (2016), 1987-2013 yılları arası Şili'de döviz kurlarından manşet ve çekirdek enflasyonlarına geçişkenliği incelemek amacıyla yaptıkları bir çalışmadır. VAR analizi ile elde edilen bulgulara göre döviz kurlarından çekirdek enflasyona geçişkenliğin manşet enflasyonuna göre daha düşük kaldığı her iki enflasyon türünde de fiyatlara tam yansımasının 3-4 ay arasında sürdügü belirlenmiştir. Ayrıca enflasyon hedeflemesi rejimine geçilmesi ile genel olarak geçişkenliğin rejim öncesine göre düştüğü ve oldukça istikrarlı seviyelerde kaldığı görülmektedir.

Forbes, Hjortsoe ve Nenova (2018), 1993-2015 yılları arası İngiltere'de döviz kurlarındaki dalgalanmaların tüketici ve ithalat fiyatlarına nasıl geçtiğini incelemek amacıyla yaptıkları bir çalışmadır. SVAR analizi ile elde edilen bulgulara göre fiyatlar, döviz kurlarındaki dalgalanmalara neyin sebep olduğuna bağlı olarak değişmektedir. Döviz kuru geçişkenliğinin iç talep şoklarına yanıt olarak düşük ancak iç para politikası şoklarına karşı ise yüksek olduğu görülmektedir.

Jasova, Moessner ve Takats (2019), 1994-2017 yılları arası 11'i gelişmiş, 22'si gelişmekte olan ülkeler üzerine döviz kurlarının tüketici fiyatlarına doğru geçişkenliğini incelemek amacıyla yaptıkları bir çalışmadır. Dinamik panel veri analizi sistem GMM yöntemi ile elde edilen bulgulara göre küresel finans krizi sonrası gelişmiş ülkelerde döviz kuru geçişkenliği görece düşük ve sabit kalırken gelişmekte olan ülkelerde ise azalmaya başlamıştır. Gelişmekte olan ülkelerdeki döviz kuru geçişkenliğinin azalmasının düşük enflasyonla ilişkili olduğu belirtilmiştir.

Isnowati, Sugiyanto, Kurnia ve Tjahjaningsih (2020), 1997-2007 yılları arası Endonezya'da döviz kurlarından yurt içi fiyatlara geçişkenliği incelemek amacıyla yaptıkları bir çalışmadır. Çoklu regresyon sonuçlarına göre genel olarak kur 
değişkenliğinin enflasyon üzerindeki etkisi oldukça yüksektir. Uzun vadede döviz kurlarından yurt içi fiyatlara geçişkenlik kısa vadede olduğundan daha fazladır.

Bhat ve Bhat (2021), 1996-2017 yılları arası Hindistan'da döviz kurlarından yurt içi fiyatlara geçişkenliğin simetrik ve asimetrik etkilerini incelemek amacıyla yaptıkları bir çalışmadır. ARDL sınır testi sonuçlarına göre kısa vadeli geçişlerin uzun vadeli geçişlerden daha düşük olduğu, genel itibariye kısmi döviz kuru geçişkenliğinin görüldügü, bunun da Hindistan'a gelen yabancı üreticilerin güçlü rekabetle karşılaşmaları ve Hindistan'ın 2016 yılında enflasyon hedeflemesi rejimine geçmesi ile açıklanmaktadır. NARDL sonuçlarına göre ise döviz kurlarındaki düşüusün yurt içi fiyatları üzerindeki uzun vadeli etkisi döviz kurlarındaki yükselişin yurt içi fiyatları üzerindeki uzun vadeli etkisinden daha yüksektir.

Edwards ve Cabezas (2021), 2003-2019 yılları arası 2008 bankacılık ve para krizi bağlamında İzlanda'nın döviz kurundan 12 alt kategoriye ayrıştııılmış fiyat endekslerine geçişkenliği incelemek amacıyla yaptıkları bir çalışmadır. En küçük kareler (EKK) ve VAR analizi ile elde edilen bulgulara göre geçişkenlik katsayısı genel olarak uzun vadede daha etkili, ürün kategorileri açısından değerlendirildiğinde döviz kurlarından uluslararası ticarete konu olan mal gruplarına geçişkenliğin uluslararası ticarete konu olmayan mal gruplarına göre daha yüksek olduğu, 2009 yılında yapısal bir kırılmanın gerçekleştiği ayrıca esnek enflasyon hedeflemesine geçilmesi ile bu geçişkenliğin düştügü görülmektedir.

\section{Veri, Data ve Metodoloji}

Bu çalışmanın amacı, 2005:1-2020:4 dönemi için Türkiye'nin çeyreklik enflasyon, döviz kuru, sanayi üretimi ve ithalat birim değer endeksi arasındaki kısa ve uzun dönemli eş bütünleşme ilişkilerini analiz etmektir. Bağımlı değişken olarak alınan enflasyon, tüketici fiyat endeksi (tüfe) değişkeni ve üretici fiyat endeksi (üfe) baz alınarak -sırasıyla model A ve model B olmak üzere- iki farklı model oluşturulmuştur. Model B'de üretici fiyat endeksi verileri 2006 yılı itibariyle oluşturulduğundan, bu modelde 2006:1-2020:3 dönemi çeyreklik verileri kullanılmıştır. Çalışmada kullanılan veriler TÜiK veri tabanından elde edilmiştir. 
Enflasyon üzerinde döviz kuru, sanayi üretimi ve ithalat birim değer endeksi etkilerinin araştııılması amacıyla aşağıdaki modeller oluşturulmuştur.

$$
\begin{aligned}
& \text { lntü } f e=f(\operatorname{lnn} d k, \operatorname{lnibde}, \ln s u ̈ e)(A)
\end{aligned}
$$

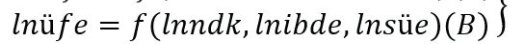

$$
\begin{aligned}
& \text { lntüf } e_{t}=a_{10}+a_{11} \operatorname{lnndk}_{t}+a_{12} \operatorname{lnibde}_{t}+a_{13} \operatorname{lnsü} e_{t}(A) \\
& \text { lnüf } \left.e_{t}=a_{20}+a_{21} \operatorname{lnndk}_{t}+a_{22} \text { lnibde }_{t}+a_{23} \ln \ln e_{t}(B)\right\} \\
& \text { lntüf } e_{t}=a_{10}+a_{11} \text { lnnd }_{t}+a_{12} \text { lnibde }_{t}+a_{13} \text { lnsü } e_{t}+\mu_{1 t}(A) \\
& \left.\ln \ddot{\mathrm{u} f} e_{t}=a_{20}+a_{21} \operatorname{lnndk_{t}}+a_{22} \operatorname{lnibde}_{t}+a_{23} \ln s \mathrm{u} e_{t}+\mu_{2 t}(B)\right\}
\end{aligned}
$$

Yukarıdaki ifadelerde (1-i) nolu modeller değişkenler arası fonksiyonel ilişkileri, (1-ii) nolu modeller matematiksel modelleri ve son olarak (1-iii) nolu modeller ise ekonometrik modelleri temsil etmektedir. Ekonometrik modellerde $a_{10}, a_{20}$ kesme terimlerini, $a_{11}, a_{12}, a_{13}, a_{21}, a_{22}$ ve $a_{23}$ bağımsız değişkenlerin bağımlı değişken üzerindeki etki katsayılarını, $u_{1 t}$ ve $u_{2 t}$ ise hata terimlerini ifade etmektedir. Model A'da tüfe değişkeni, model B'de ise üfe değişkeni bağımlı değişken olarak tanımlanmıştır. Verilerin durağanlık sınaması için yapısal kırılmasız birim kök testlerinden olan Artırılmış Dickey-Fuller (ADF) (1981) ve Phillips-Perron (PP) testleri (1988), değişkenler arası uzun ve kısa dönemli eşbütünleşme durumunu test etmek için ARDL sınır testi uygulanmıştır. Ayrıca serilerin logaritmik formları ile çalışılmıştır.

\subsection{Teorik çerçeve}

\subsubsection{Birim Kök Testleri: ADF ve PP}

Serilerin durağanlık seviyelerinin tespiti, ekonometrik analiz yapabilmek için oldukça önemlidir. Özellikle eşbütünleşme testlerinde sahte regresyon olgusuna düşmemek için gereklidir. Her ne kadar Pesaran, Shin ve Smith (2001) tarafından geliştirilen ARDL eşbütünleşme testinde aynı seviyede durağan olma şartı aranmıyorsa da bu testte de değişkenlerin I(0) veya I(1) olmaları, I(2) olmamaları gerektiğinden yine birim kök testi uygulanmalıdır. Bu çalışmada, değişkenlere ADF ve PP birim kök testleri uygulanacaktır. ADF, DF testinin daha yüksek dereceden otoregresif süreçlere uygulanabilmesi için modifiye edilmiş halidir. ADF testi üç model şeklinde uygulanabilir. Modeller aşağıdaki şekilde tanımlanır. 


$$
\begin{gathered}
\Delta Y_{t}=\delta Y_{t-1}+\sum_{i=1}^{p} \delta_{i} \Delta Y_{t-i}+\varepsilon_{t} \\
\Delta Y_{t}=c+\delta Y_{t-1}+\sum_{i=1}^{p} \delta_{i} \Delta Y_{t-i}+\varepsilon_{t} \\
\Delta Y_{t}=c+\beta t+\delta Y_{t-1}+\sum_{i=1}^{p} \delta_{i} \Delta Y_{t-i}+\varepsilon_{t}
\end{gathered}
$$

1. Model kesmesiz-trendsiz (none), 2. Model kesmeli- trendsiz (intercept) ve 3. Model ise kesmeli-trendli (trend) modeli temsil etmektedir. Uygun gecikme uzunluğu Akaike ve Schwarz gibi bilgi kriterlerince tespit edilmektedir. Kritik değerler için MacKinnon (1996) tarafından geliştirilen değerler kullanılacaktır. Phillips-Peron (1988) da üç regresyon modeli kullanmaktadır. Fakat ADF testine serisel korelasyon ve heteroskedastisiti problemini dikkate alan bir parametrik olmayan düzeltme uygulamaktadır (Sevüktekin ve Çınar, 2017).

\subsubsection{ARDL sınır testi}

Zaman serisi analizlerinde farklı eşbütünleşme yöntemleri kullanılabilmektedir. Pesaran ve ark. (2001) tarafından geliştirilen ARDL sınır testi diğer testlere göre bazı yönleriyle üstündür. Değişkenlerin I(2) olmaları dışındaki tüm durumlarda kullanılabilecek bir yöntemdir. Ayrıca değişkenlerin aynı seviyede durağan olma şartını gerektirmeyen bu yöntem sınırlı sayıda gözlem içeren veriler için de güvenilir sonuçlar verme üstünlüğüne sahiptir. Model A ve B için eşbütünleşme modelleri aşağıdaki şekilde kurulabilir:

Model A:

$$
\begin{aligned}
& \Delta \operatorname{lntü} f e_{t}=\alpha_{10}+\sum_{j=1}^{m} \alpha_{1 j} \Delta \operatorname{lntü} f e_{t-j}+\sum_{j=0}^{n} \beta_{1 j} \Delta l n n d k_{t-j}+\sum_{j=0}^{k} \sigma_{1 j} \Delta l n i b d e_{t-j} \\
& +\sum_{j=0}^{k} \delta_{1 j} \Delta l n s u ̈ e_{t-j}+\gamma_{11} \ln t \ddot{\mathrm{u} f} e_{t-1}+\gamma_{12} l n n d k_{t-1}+\gamma_{13} l n i b d e_{t-1}+\gamma_{14} l n s \ddot{u} e_{t-1}+\mu_{1 t}
\end{aligned}
$$

Model B:

$$
\begin{aligned}
& \Delta l n \ddot{\mathrm{f}} f e_{t}=\alpha_{20}+\sum_{j=1}^{m} \alpha_{2 j} \Delta \operatorname{lnü} f e_{t-j}+\sum_{j=0}^{n} \beta_{2 j} \Delta l n n d k_{t-j}+\sum_{j=0}^{k} \sigma_{2 j} \Delta l n i b d e_{t-j} \\
& +\sum_{j=0}^{k} \delta_{2 j} \Delta \text { lnsü } e_{t-j}+\gamma_{21} l n \ddot{u} f e_{t-1}+\gamma_{22} \operatorname{lnndk}_{t-1}+\gamma_{23} \text { lnibde }_{t-1}+\gamma_{24} l n s u ̈ e_{t-1}+\mu_{2 t}
\end{aligned}
$$

Burada $\sum_{k=1}^{2} \sum_{l=1}^{4} \gamma_{k l}$ katsayıları uzun dönem, $\sum_{k=1}^{2} \alpha_{k j}, \beta_{k j} \sigma_{k j}, \delta_{k j}$ katsayıları kısa dönem etkilerini ifade etmektedir. Değişkenler arasında eşbütünleşmeyi test eden boş hipotez eşbütünleşmenin olmadığını, alternatif hipotez ise eşbütünleşmenin 
olduğunu ifade etmektedir. Boş (veya sıfır) hipotez aşağıdaki gibidir:

$$
H_{0}=\sum_{k=1}^{2} \sum_{l=1}^{4} \gamma_{k l}=0
$$

Pesaran ve ark. (2001) tarafından belirlenen düzeyde I(0) ve birinci fark seviyesinde I(1) kritik değerler ile analiz sonucu bulunan $F$ istatistik değeri karşılaştırılır. Hesaplanan F istatistik değeri, I(1) değerinden büyük ise boş hipotez reddedilir ve böylece modelde eşbütünleşme olduğu tespit edilir. I(0) değerinden küçük ise eşbütünleşmenin olmadığını varsayan boş hipotez kabul edilir. Son olarak hesaplanan değer I(0) ve I(1) kritik değerleri arasında ise eşbütünleşme ile ilgili olumlu veya olumsuz bir sonuca varılamaz. Yani ARDL sınır testi bu sınama için uygun değildir, başka yöntemler kullanılarak daha uygun sonuçlar alınabilir. Ayrıca kısa dönem ilişkilerinin tespiti için hata düzeltme modeli de aşağıdaki gibi alınabilir:

Model A:

$$
\begin{gathered}
\Delta \operatorname{lntüf} e_{t}=\alpha_{10}+\sum_{j=1}^{m} \alpha_{1 j} \Delta \operatorname{lntü} f e_{t-j}+\sum_{j=0}^{n} \beta_{1 j} \Delta l n n d k_{t-j}+\sum_{j=0}^{k} \sigma_{1 j} \Delta l n i b d e_{t-j} \\
+\sum_{j=0}^{k} \delta_{1 j} \Delta l n s u ̈ e_{t-j}+\varphi_{1} E C M_{t-1}+\mu_{1 t}
\end{gathered}
$$

Model B:

$$
\begin{gathered}
\Delta \operatorname{lnü} f e_{t}=\alpha_{20}+\sum_{j=1}^{m} \alpha_{2 j} \Delta \ln \ddot{\mathrm{u}} f e_{t-j}+\sum_{j=0}^{n} \beta_{2 j} \Delta \operatorname{lnn} d k_{t-j}+\sum_{j=0}^{k} \sigma_{2 j} \Delta \operatorname{lnibde_{t-j}} \\
+\sum_{j=0}^{k} \delta_{2 j} \Delta \ln s \ddot{u} e_{t-j}+\varphi_{2} E C M_{t-1}+\mu_{2 t}
\end{gathered}
$$

Model A ve B'de uzun dönemli bir ilişki tespit edilebilirse kısa dönemde oluşacak sapmaların düzeltilme katsayısını veren hata terimi katsayıları $\varphi_{1}$ ve $\varphi_{2}$, negatif değerli ve istatistiki olarak anlamlı olmalıdır.

\subsection{Ampirik Bulgular}

Değişkenlere ADF ve PP birim kök testleri uygulanmış ve sonuçları tablo 1'de verilmiştir. 
Tablo 1: Birim Kök Test Sonuçları

\begin{tabular}{|c|c|c|c|c|}
\hline & \multicolumn{4}{|c|}{ Sabitli } \\
\hline & ADF & PP & $\Delta \mathrm{ADF}$ & $\Delta \mathrm{PP}$ \\
\hline Intüfe & 2,051936 & 2,503692 & $-7,487884^{*}(0)$ & $-7,463409 *(3)$ \\
\hline Inüfe & 1,836530 & 2,192653 & $-4,786894 *(0)$ & $-4,838231 *(1)$ \\
\hline Inndk & 1,938923 & 2,849351 & $-6,665538 *(0)$ & $-6,665538 *(0)$ \\
\hline Insüe & $-0,755650$ & $-0,533333$ & $-9,612450 *(0)$ & $-9,787812^{*}(3)$ \\
\hline \multirow[t]{3}{*}{ Inibde } & $-2,779381^{* \star *}(1)$ & $-1,695863$ & $-5,100582 *(1)$ & $-3,861679 *(12)$ \\
\hline & \multicolumn{4}{|c|}{ Sabitli ve trendli } \\
\hline & ADF & PP & $\Delta \mathrm{ADF}$ & $\Delta \mathrm{PP}$ \\
\hline Intüfe & $-0,042002$ & 0,302487 & $-7,957131 *(0)$ & $-7,941916 *(7)$ \\
\hline Inüfe & $-0,553041$ & $-0,21929$ & $-5,248641 *(0)$ & $-5,281351 *(1)$ \\
\hline Inndk & $-1,094485$ & $-0,905193$ & $-7,271334 *(0)$ & $-7,918089 *(6)$ \\
\hline Insüe & $-3,246013$ & $-3,190696 * * *(2)$ & $-9,532053 *(0)$ & $-9,699376 *(3)$ \\
\hline Inibde & $-2,955638$ & $-2,227852$ & $-5,265577 *(1)$ & $-3,759724 * \star(13)$ \\
\hline
\end{tabular}

Not: Gecikme uzunlukları Schwarz bilgi kriterine göre belirlenmiştir. Parantez içi sayılar optimal gecikme uzunluğudur. $\Delta$ sembolü birinci fark anlamında kullanılmışıı.***, ,*,* sırasıyla\%10, \%5,\%1 düzeylerine karşılık gelmektedir.

Tablo 1 incelendiğinde tüfe, üfe, nominal döviz kuru, sanayi üretim endeksi ve ithalat birim değer endeksi değişkenleri ADF ve PP birim kök testlerinin her iki model (sabitli (intercept), sabitli ve trendli (trend)) sonuçlarına göre düzeyde durağan dışı, birinci farkta ise \%1 anlamlılık seviyesinde durağandırlar. Sadece ithalat birim endeksi değişkeni iki yerde farklı sonuçlar vermiştir. Diğerlerinden farklı olarak ADF testinin sabitli (intercept) modeline göre düzeyde \%10 anlamlılık düzeyinde durağandır, aynı değişkenin PP birim kök testi sonucuna göre ise sabitli ve trendli (trend) modelin birinci fark seviyesinde \%5 anlamlılık düzeyinde durağandır. Sonuç olarak \%10 anlamlılık düzeyi dikkate alınmaz ise tüm değişkenlerin düzeyde durağan olmadıkları, birinci fark düzeyinde I(1) durağan oldukları sonucuna varılabilir.

Tablo 2: ARDL Sınır Testi Sonuçları

\begin{tabular}{|l|c|c|c|c|c|c|}
\hline \multirow{2}{*}{ Model A } & k & F-istatistiği & \multicolumn{2}{|c|}{ \%5 kritik değerler } & \multicolumn{2}{|c|}{ \%1 kritik değerler } \\
\cline { 2 - 7 } & 3 & 13,46436 & $I(0) 2,62$ & $I(1) 4,615$ & $I(0) 4,748$ & $I(1) 6,188$ \\
\hline Model B & 3 & 7,240772 & $I(0) 3,408$ & $I(1) 4,623$ & $I(0) 4,828$ & $I(1) 6,195$ \\
\hline
\end{tabular}

Not: Kritik değerler belirlenirken, model A için 65 veri ve case 3, model B için ise 55 veri ve case 3 dikkate alınmştır. 
Tablo 2'de verilmiş olan ARDL sınır testi sonuçlarına göre her iki model için hesaplanan F istatistik değerleri I(1) kritik değerlerinden \%1 anlamlılık düzeyinde büyük olduğu için eşbütünleşmenin olmadığını ifade eden sıfır hipotezi reddedilir, dolayısıyla değişkenler arası eşbütünleşme ilişkisi olduğunu ifade eden alternatif hipotez kabul edilir.

Model A ve B'nin uzun ve kısa dönem katsayıları aşağıdaki tablolarda verilmiştir.

Tablo 3: Uzun Dönem Katsayıları

\begin{tabular}{|l|c|c|c|c|c|}
\hline & Değişken & Katsayı & Std. Hata & t-istatistiği & Olasılıkdeğeri \\
\hline \multirow{3}{*}{ Model A } & LNSUE & 0,372239 & 0,138907 & 2,679776 & $0,0108^{* *}$ \\
\cline { 2 - 6 } & LNNDK & 0,693080 & 0,064844 & 10,68841 & $0,0000^{*}$ \\
\cline { 2 - 6 } & LNIBDE & 0,586896 & 0,137979 & 4,253517 & $0,0001^{*}$ \\
\hline \multirow{3}{*}{ Model B } & LNSUE & $-0,063681$ & 0,032429 & $-1,963718$ & $0,0596^{* * *}$ \\
\cline { 2 - 6 } & LNNDK & 0,824899 & 0,016177 & 50,99108 & $0,0000^{*}$ \\
\cline { 2 - 6 } & LNIBDE & 0,725650 & 0,048062 & 15,09818 & $0,0000^{*}$ \\
\hline
\end{tabular}

Not: ***,**** sırasıyla\%10, \%5,\%1 düzeylerine karşılık gelmektedir.

Tablo 3'te görüldügüu üzere, model A'da nominal döviz kuru ve ithalat birim endeksi katsayıları \%1, sanayi üretim endeksi katsayısı ise \%5 seviyesinde istatistiki olarak anlamlıdır. Sanayi üretim endeksinde oluşacak \%1'lik artış, tüketici fiyat endeksi değişkeninde \%0,37'lik artışa; nominal döviz kurundaki \%1'lik artış, tüketici fiyat endeksi değişkeninde \%0,69'luk artışa; ithalat birim değer endeksindeki \%1'lik artış ise tüketici fiyat endeksi değişkeninde \%0,58'lik artışa neden olmaktadır. Model B'de ise nominal döviz kuru ve ithalat birim endeksi değişkeni \%1 seviyesinde istatistiki olarak anlamlıdır. Ancak sanayi üretim endeksi değişkeni \%5 seviyesi dikkate alındığında, istatistiki olarak anlamlı değildir. Sanayi üretim endeksi değişkeni anlamlı olmadığından katsayı ilişkisi göz ardı edilebilir. Ancak nominal döviz kurundaki \%1'lik artış, üretici fiyat endeksinde \%0,82'lik artışa, ithalat birim değer endeksindeki \%1'lik artış, üretici fiyat endeksinde $\% 0,73^{\prime} l u ̈ k$ artışa yol açmaktadır.

Modellerin kısa dönem katsayıları aşağıdaki tablolarda verilmiştir. 
Tablo 4: ARDL $(4,4,0,7)$ Sınır Testi Kısa Dönem Katsayıları (Model A)

\begin{tabular}{|c|c|c|c|c|}
\hline Değişken & Katsayı & Std. Hata & t-istatistiği & Olasılıkdeğeri \\
\hline $\mathrm{C}$ & 0,108843 & 0,014428 & 7,543988 & $0,0000^{*}$ \\
\hline $\mathrm{D}($ LNTUFE $(-1))$ & $-0,116552$ & 0,111571 & $-1,044644$ & 0,3028 \\
\hline D(LNTUFE(-2)) & $-0,194368$ & 0,105178 & $-1,848003$ & $0,0724 * * *$ \\
\hline D(LNTUFE(-3)) & $-0,194523$ & 0,106077 & $-1,833788$ & $0,0745^{\star * *}$ \\
\hline D(LNSUE) & $-0,004090$ & 0,034823 & $-0,117439$ & $0,9071^{* * *}$ \\
\hline $\mathrm{D}(\mathrm{LNSUE}(-1))$ & 0,041598 & 0,040978 & 1,015130 & 0,3165 \\
\hline D(LNSUE(-2)) & $-0,069720$ & 0,046122 & $-1,511624$ & 0,1389 \\
\hline $\mathrm{D}($ LNSUE $(-3))$ & $-0,114194$ & 0,059513 & $-1,918816$ & $0,0625^{* * *}$ \\
\hline $\mathrm{D}(\mathrm{LNIBDE})$ & 0,164226 & 0,044472 & 3,692798 & $0,0007^{*}$ \\
\hline $\mathrm{D}(\mathrm{LNIBDE}(-1))$ & $-0,076315$ & 0,050903 & $-1,499221$ & 0,1421 \\
\hline $\mathrm{D}(\mathrm{LNIBDE}(-2))$ & 0,060677 & 0,052716 & 1,151018 & 0,2569 \\
\hline $\mathrm{D}(\mathrm{LNIBDE}(-3))$ & 0,019099 & 0,053143 & 0,359395 & 0,7213 \\
\hline $\mathrm{D}(\mathrm{LNIBDE}(-4))$ & 0,012158 & 0,051006 & 0,238356 & 0,8129 \\
\hline $\mathrm{D}(\mathrm{LNIBDE}(-5))$ & $-0,157373$ & 0,048813 & $-3,224017$ & $0,0026^{*}$ \\
\hline $\mathrm{D}(\mathrm{LNIBDE}(-6))$ & 0,082690 & 0,042838 & 1,930309 & $0,0611^{\star * *}$ \\
\hline CointEq(-1) & $-0,149489$ & 0,022650 & $-6,599845$ & $0,0000 *$ \\
\hline
\end{tabular}

Not: ***,**,* sırasıyla\%10, \%5,\%1 düzeylerine karşılık gelmektedir.

Tablo 4 incelendiğinde, hata kesme terimi istatistiki olarak \%1 anlamlılık düzeyinde anlamlıdır. Hata teriminin katsayısı beklendiği üzere negatif değerlidir. Yani uzun dönem ilişkisi olan modelde kısa dönemde oluşacak sapmalar belli bir süre sonra dengelenecektir. Model A'da tüketici fiyat endeksinde meydana gelecek 1 birimlik sapma bir sonraki dönem \% 15 düzeltilecektir. Yaklaşık 7 dönem sonra model dengelenecektir.

Tablo 5: ARDL $(4,4,4,8)$ Sınır Testi Kısa Dönem Katsayıları (Model B)

\begin{tabular}{|c|c|c|c|c|}
\hline Değişken & Katsayı & Std. Hata & t-istatistiği & Olasılık değeri \\
\hline C & 0,953607 & 0,168131 & 5,671799 & $0,0000^{*}$ \\
\hline $\mathrm{D}(\mathrm{LNUFE}(-1))$ & 0,321574 & 0,121659 & 2,643238 & $0,0133^{* \star}$ \\
\hline $\mathrm{D}(\operatorname{LNUFE}(-2))$ & 0,115073 & 0,120662 & 0,953687 & 0,3484 \\
\hline D(LNUFE(-3)) & 0,324695 & 0,092201 & 3,521586 & $0,0015^{\star}$ \\
\hline $\mathrm{D}$ (LNSUE) & $-0,063731$ & 0,031089 & $-2,049934$ & $0,0498^{* *}$ \\
\hline $\mathrm{D}(\mathrm{LNSUE}(-1))$ & 0,057233 & 0,037503 & 1,526105 & 0,1382 \\
\hline $\mathrm{D}(\mathrm{LNSUE}(-2))$ & $-0,017255$ & 0,047020 & $-0,366968$ & 0,7164 \\
\hline $\mathrm{D}($ LNSUE $(-3))$ & 0,178230 & 0,062009 & 2,874281 & $0,0076^{*}$ \\
\hline $\mathrm{D}(\mathrm{LNNDK})$ & 0,428878 & 0,026379 & 16,25827 & $0,0000 *$ \\
\hline $\mathrm{D}($ LNNDK $(-1))$ & $-0,150452$ & 0,063471 & $-2,370402$ & $0,0249 * *$ \\
\hline
\end{tabular}




\begin{tabular}{|c|c|c|c|c|}
\hline $\mathrm{D}(\mathrm{LNNDK}(-2))$ & $-0,112936$ & 0,055457 & $-2,036457$ & $0,0513^{* * *}$ \\
\hline $\mathrm{D}(\mathrm{LNNDK}(-3))$ & $-0,195127$ & 0,045892 & $-4,251844$ & $0,0002 *$ \\
\hline $\mathrm{D}(\mathrm{LNIBDE})$ & 0,628938 & 0,043630 & 14,41541 & $0,0000 *$ \\
\hline $\mathrm{D}(\mathrm{LNIBDE}(-1))$ & $-0,259438$ & 0,090138 & $-2,878240$ & $0,0076^{*}$ \\
\hline $\mathrm{D}(\mathrm{LNIBDE}(-2))$ & $-0,166527$ & 0,085891 & $-1,938813$ & $0,0627^{* * *}$ \\
\hline $\mathrm{D}(\mathrm{LNIBDE}(-3))$ & $-0,268185$ & 0,077518 & $-3,459654$ & $0,0018^{*}$ \\
\hline $\mathrm{D}(\mathrm{LNIBDE}(-4))$ & 0,006510 & 0,047730 & 0,136383 & 0,8925 \\
\hline $\mathrm{D}(\mathrm{LNIBDE}(-5))$ & $-0,045542$ & 0,044235 & $-1,029548$ & 0,3120 \\
\hline $\mathrm{D}(\mathrm{LNIBDE}(-6))$ & $-0,100339$ & 0,046063 & $-2,178282$ & 0,0380 ** \\
\hline $\mathrm{D}(\mathrm{LNIBDE}(-7))$ & $-0,058191$ & 0,042981 & $-1,353867$ & 0,1866 \\
\hline CointEq(-1) & $-0,557167$ & 0,098392 & $-5,662709$ & $0,0000^{*}$ \\
\hline
\end{tabular}

Not: ***, **,* sırasıyla\%10, \%5,\%1 düzeylerine karşılık gelmektedir.

Üretici fiyat endeksinin bağımlı değişken olduğu Model B'de, hata terimi katsayısı \%1 seviyesinde anlamlı ve negatif değerlidir. Modelde kısa dönemde oluşacak 1 birimlik sapma sonraki dönem \%58 düzeltilecektir. Yani yaklaşık 2 dönemde sapma dengelenecektir.

Modellerin diognastik verileri aşağıdaki tabloda verilmiştir.

Tablo 6: Diognastik test sonuçları

\begin{tabular}{|l|l|c|c|}
\hline \multirow{4}{*}{ Model A } & Test & istatistik & Olaslılık \\
\cline { 2 - 4 } & Breusch-Godfrey Otokorelasyon & 0,444731 & 0,6445 \\
\cline { 2 - 4 } & Breusch-Pagan-Godfrey Değişen Varyans & 0,693845 & 0,7954 \\
\cline { 2 - 4 } & Ramsey RESET & 1,351448 & 0,2525 \\
\cline { 2 - 4 } & Jargue-Bera Normallik & 0,145213 & 0,929967 \\
\hline \multirow{4}{*}{ Model B } & Breusch-Godfrey Otokorelasyon & 0,850016 & 0,4389 \\
\cline { 2 - 4 } & Breusch-Pagan-Godfrey Değişen Varyans & 0,613238 & 0,8826 \\
\cline { 2 - 4 } & Ramsey RESET & 2,034871 & 0,1652 \\
\cline { 2 - 4 } & Jargue-Bera Normallik & 1,344353 & 0,510596 \\
\hline
\end{tabular}

Tablo 6'da görüldüğü üzere, modellerin ikisinde de otokorelasyon, değişen varyans ve spesifikasyon probleminin olmadığı görülmektedir. Ayrıca Jargue-Bera normallik testinin olasılık değerlerinin 0,5 'ten büyük olması, hata terimlerinin de normal dağıldığını göstermektedir.

Modellerin kararlılık testleri sonuçları aşağıdaki grafiklerde verilmiştir. 


\section{Şekil 1. Kararlılık Test Sonuçları}

Model A
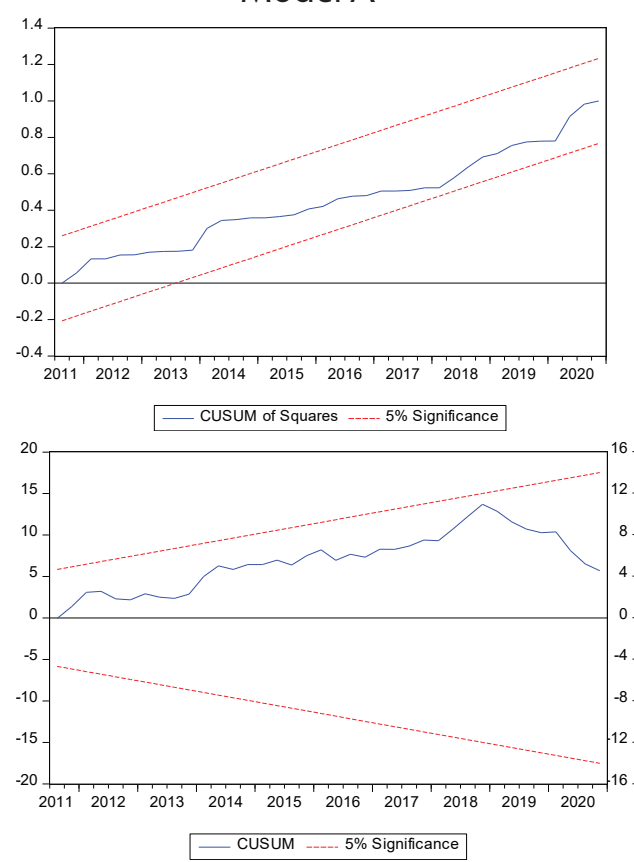

Model B
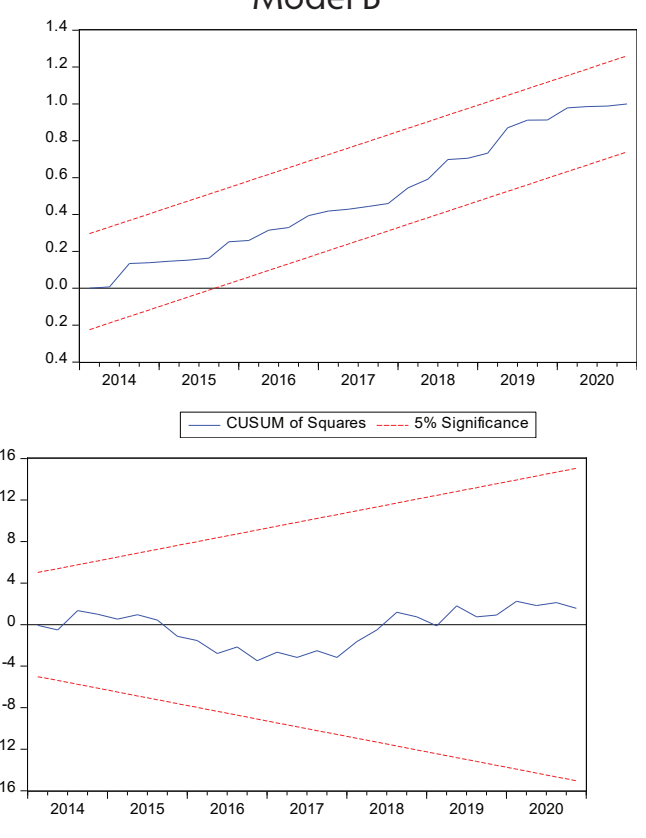

Ardışık hataların ve karelerinin toplamının belli bir güven aralığında kalması modelde yapısal kırılmanın olmadığını gösterir. Bunu test etmek için uygulanan CUSUM ve CUSUMQ kararlılık testi sonuçlarına göre modellerde yapısal kırılmanın olmadığı tespit edilmiştir.

\section{Sonuç}

Gelişmekte olan piyasalar içerisinde yer alan Türkiye'nin ticari ve finansal serbestleşmenin artttığı 1980 ve 90'lı yıllardan sonra ihracata dayalı ekonomik büyüme modelini benimsemesi ve daha fazla dışa açılma kararı -ihracat için daha fazla ithal girdi gerektiğinden- beraberinde cari açı̆̆ı giderek artırmış, bu da döviz kurlarındaki dalgalanmalara karşı son derece kırılgın bir ekonomik yapı oluşturmuştur. Bu bakımdan Türkiye'nin son dönem ekonomik tarihi, döviz 
kurlarında gerçekleşen sert yükselişler ve bundan etkilenen pek çok makro iktisadi değişkenler arasındaki ilişkilerin tartışıldığı, incelendiği iktisat yazını ile doludur. Özellikle döviz kurlarındaki dalgalanmaların yurt içi üretici ve tüketici fiyatları üzerindeki etkisi ise literatürde ayrı bir araştırma konusudur. Ulusal fiyatların döviz kurları şoklarına karşı duyarlılığını ifade eden döviz kuru geçişkenliği, ithalata bağımlılığı yüksek olan ülkeler arasında popülerliğini devam ettiren araştırma alanlarından biridir. Bu nedenle döviz kurlarının yurt içi fiyatlar üzerinde ne derece bir etkiye sahip olduğu meselesi, uzun yıllardır Türkiye'nin karşılaştığı makro iktisadi problemlerinden biri olmaya devam etmektedir.

Türkiye'de döviz kurlarından yurt içi üretici ve tüketici fiyatlarına geçişkenliğin derecesini ölçmek amacıyla yapılan bu çalışmada, 2005:1-2020:4 yılları arası Türkiye'nin enflasyon, döviz kuru, sanayi üretimi ve ithalat birim değer endeksi arasındaki kısa ve uzun dönemli eşbütünleşme ilişkileri irdelenmiş ve analiz bulguları elde edilmiştir. Enflasyon değişkenini temsilen, yurt içi üretici (ÜFE) ve yurt içi tüketici (TÜFE) endekslerinden ayrı modeller oluşturulmuştur. Illk modelde TÜFE ile nominal döviz kuru, sanayi üretim endeksi ve ithal birim endekslerinin anlamlı olduğu, sanayi üretim endeksi, nominal döviz kuru ve ithalat birim değer endeksindeki \%1'lik bir artışın sırasıyla \%0,37, \%0,69 ve \%0,58'lik artışa; diğer modelde ise ÜFE ile döviz kuru ve ithal birim endeksleri arasındaki ilişkinin anlamlı olduğu, nominal döviz kuru ve ithalat birim değer endeksindeki \%1'lik bir artışın sırasıyla \%0,82 ve \%0,73'lük artışa yol açtığı belirlenmiştir.

Elde edilen bu bulgulara göre Türkiye'de yurtiçi tüketici fiyatları üzerinde döviz kuru, sanayi üretimi ve ithal fiyatların; yurt içi üretici fiyatları üzerinde ise döviz kuru ve ithal fiyatların etkili olduğu tespit edilmiştir. Her iki modelde de yurt içi fiyatlar üzerinde en fazla etkili olan faktör nominal döviz kurudur. TÜFE'de 0,69, ÜFE'de ise 0,82 katsayıları teorik literatürde "kısmi geçişkenlik" diye açıklanmış olsa da yine de bu katsayılar güçlü bir geçişkenliği ifade etmektedir. Ayrıca bu geçişkenliğin yurt içi üretici fiyatlarında daha fazla olduğunu da vurgulamak gerekir. Bunun nedeni ise Türkiye'nin ihracat yapabilmek için yoğun miktarda ithal girdiye ihtiyaç duymasıdır. Uzun yıllardan beri ihraç ürünlerin içerisindeki ithal girdi oranı hala yüksek seviyelerdedir. Kur baskısı önce üretici fiyatlarına ve 
maliyetlere yansımaktadır. Leigh ve Marco Rossi (2002), Hyder ve Shah (2004), İto ve Sato (2008), Alptekin ve ark. (2016), Karaoğlu ve Kılıçkaplan (2018), Güler (2020) tarafından yapılan çalışmalarda da benzer bulgu ve açıklamaların yapıldığı görülmektedir. Genel itibariyle bu bulgulardan bir çıkarım yapmak gerekirse, döviz kurlarından hem yurt içi üretici hem de yurt içi tüketici fiyatlarına geçişkenliğin varlığı söz konusudur. Çalışmada analiz edilen bu sonuçlar, gerek yerli gerekse yabancı literatürün hemen hemen tamamına paralellik göstermektedir. Türkiye'de döviz kurlarından yurt içi üretici ve tüketici fiyatlarına doğru bu güçlü geçiş etkisini sınırlandırma ve ortadan kaldırmanın yolu, Türkiye'nin uzun yıllardır ihraç yapma kapasatesinin ithal ara malına olan bağımlılığından kurtulmaktan geçmektedir. Nitekim bu, köklü revizyonu gerektiren iktisadi politikaların neticesinde ortaya çıacak bir sorundur.

\footnotetext{
Hakem Değerlendirmesi: Dış bağımsız.

Çıkar Çatışması: Yazarlar çıkar çatışması bildirmemiştir.

Finansal Destek: Yazarlar bu çalışma için finansal destek almadığını beyan etmiştir.

Peer-review: Externally peer-reviewed.

Conflict of Interest: The authors have no conflict of interest to declare.

Grant Support: The authors declared that this study has received no financial support.
}

\section{Kaynaklar/References}

Akdemir, S. ve Özçelik, M. (2018). Döviz kurlarının yurtiçi fiyatlara geçiş etkisi: Türkiye ekonomisi 2003-2017 dönemi uygulaması. Ekonomik ve Sosyal Araştırmalar Dergisi, 14(1), 35-50.

Alptekin, V., Yılmaz, K. Ç. ve Taş, T. (2016). Döviz kurundan fiyatlara geçiş etkisi: Türkiye örneği. Selçuk Üniversitesi Sosyal Bilimler Enstitüsü Dergisi, 35, 1-9.

Altıntaş, H. (2014). Türkiye'de döviz kurunun enflasyon üzerine geçiş etkisinin ekonometrik analizi: 1987-2011. Uludağ Üniversitesi Iktisadi ve İdari Bilimler Fakültesi Dergisi, 33(1), 163-201.

Arı, A. (2010). Dalgalanma korkusu ve döviz kuru geçiş etkisi. Journal of Yasar University, 17(5), 2832-2841.

Baş, G. ve Kara, M. (2020). Döviz kurunun yurt içi fiyatlar üzerine geçiş etkisi: Türkiye ekonomisi üzerine bir araştırma. İşletme ve iktisat Çalışmaları Dergisi, 8(2), 115-125.

Bayat, T., Özcan, B. ve Taş, Ş. (2015). Türkiye'de döviz kuru geçiş etkisinin asimetrik nedensellik testleri ile analizi. Eskişehir Osmangazi Üniversitesi Iktisadi ve Idari Bilimler Fakültesi Dergisi, 10(2), 7-30.

Betts, C., \& Devereux, M. (2000). Exchange rate dynamics in a model of pricing-to-market. Journal of International Economics, 50(1), 215-244.

Bhat, J. A., \& Bhat, S. A. (2021). On the dynamics of exchange rate pass-through: asymmetric 
evidence from India. International Journal of Emerging Markets.

Campa, J. M., \& Goldberg, L. S. (2005). Exchange rate pass-through into import prices. The Review of Economics and Statistics, 87(4), 679-690.

Campa, J. M., \& Minguez, J. M. (2006). Differences in exchange rate pass-through in the euro area. European Economic Review, 50(1), 121-145.

Delatte, A.-L., \& Villavicencio, A. L. (2012). Asymmetric exchange rate pass-through: Evidence from major countries. Journal of Macroeconomics, 34, 833-844.

Dickey, D. A., \& Fuller, W. A. (1981). Likelihood ratio statistics for autoregressive time series with a unit root. Econometrica: Journal of the Econometric Society, 49(4), 1057-1072.

Dikkaya, M. ve Özyakışır, D. (2006). Küreselleşme ve bilgi toplumu: Eğitimin küreselleşmesi ve neoliberal politikaların etkileri. Uluslararası Illiskiler Dergisi, 3(9), 151-172.

Donayre, L., \& Panovska, I. (2016). State-dependent exchange rate pass-through behavior. Journal of International Money and Finance, 64, 170-195.

Edwards, S., \& Cabezas, L. (2021). Exchange rate pass-through, monetary policy, and real exchange rates: Iceland and the 2008 crises. Cambridge: Nber Working Paper Series Working Paper 28520.

Fischer, S. (2001). Distinguished lecture on economics in government: Exchange rate regimes: Is the bipolar view correct? The Journal of Economic Perspectives, 15(2), 3-24.

Flamini, A. (2007). Inflation targeting and exchange rate pass-through. Journal of International Money and Finance, 26(7), 1113-1150.

Forbes, K., Hjortsoe, I., \& Nenova, T. (2018). The shocks matter: Improving our estimates of exchange rate pass-through. Journal of International Economics, 114, 255-275.

Frimpong, S., \& Adam, A. M. (2010). Exchange rate pass-through in Ghana. International Business Research, 3(2), 186-192.

Goldberg, P. K., \& Knetter, M. (1997). Goods prices and exchange rates: What have we learned? Journal of Economic Literature, 35(3), 1243-1272.

Göktaş, P. (2019). Türkiye'de döviz kurunun tüketici fiyatları üzerindeki asimetrik geçiş etkileri. Sosyoekonomi, 27(42), 29-50.

Güler, A. (2020 Mayıs). Döviz kuru geçiş etkisi: Türkiye örneği. 20. Uluslararası ekonometri, yöneylem araştırması ve istatistik sempozyumu (s. 41-51). Ankara: Ankara Hacı Bayram Veli Üniversitesi.

Hyder, Z., \& Shah, S. (2004). Exchange rate pass-through to domestic prices in Pakistan. State Bank of Pakistan Working Papers No.5.

Isnowati, S., Sugiyanto, F., Kurnia, A. S., \& Tjahjaningsih , E. (2020). Exchange rate pass through viewed from wholesale price in Indonesia. Montenegrin Journal of Economics, 16(3), 137-147.

Ito, T., \& Sato, K. (2008). Exchange rate changes and inflation in post-crisis Asian economies: Vector autoregression analysis of the exchange rate pass-through. Journal of Money, Credit and Banking, 40(7), 1407-1438.

Jasova, M., Moessner, R., \& Takats, E. (2019). Exchange rate pass-through: What has changed since 
the crisis? International Journal of Central Banking, 15(3), 27-58.

Kara, H. ve Ögünç, F. (2012). Döviz kuru ve ithalat fiyatlarının yurt içi fiyatlara etkisi. Iktisat Işletme ve Finans, 27(317), 9-28.

Karaoğlu, N. ve Kılıçkaplan, S. (2018). Döviz kurunun yurt içi fiyatlara geçiş etkisinin yumuşak geçişli regresyon modeliyle tahmini. Bulletin of Economic Theory and Analysis, 3(3), 195-215.

Kaya, H. (2018). 2001 krizi sonrası Türkiye'de döviz kuru ve enflasyon ilişkisi: Döviz kuru geçiş etkisinin VAR analizi. Ankara Üniversitesi SBF Dergisi, 73(3), 841-865.

Koç, P. (2018). Türkiye'de geçiş etkisi hipotezinin geçerliliği: Bir doğrusal olmayan zaman serisi analizi. Bartın Üniversitesi İktisadi ve İdari Bilimler Fakültesi Dergisi, 9(17), 1-12.

Korhonen, I., \& Wachtel, P. (2006). A note on exchange rate pass-through in CIS countries. Research in International Business and Finance, 20(2), 215-226.

Leigh, D., \& Rossi, M. (2002). Exchange rate pass-through in Turkey. IMF Working Paper WP/02/204. López-Villavicencio, A., \& Mignon, V. (2017). Exchange rate pass-through in emerging countries: Do the inflation environment, monetary policy regime and central bank behavior matter? Journal of International Money and Finance, 79, 20-38.

MacKinnon, J. G. (1996). Numerical distribution functions for unit root and cointegration tests. Journal of Applied Econometrics, 11(6), 601-618.

Menon, J. (1995). Exchange rate pass-through. Journal of Economic Surveys, 9(2), 197-231.

Özdamar, G. (2015). Türkiye ekonomisinde döviz kuru geçiş etkisi: ARDL-sınır testi yaklaşımı. Akdeniz i.I.B.F. Dergisi, 32, 66-97.

Pesaran, M. H., Shin, Y., \& Smith, R. P. (2001). Bounds testing approaches to the analysis of level relationships. Journal of Applied Econometrics, 16(3), 289-326.

Phillips, P. C., \& Perron, P. (1988). Testing for a unit root in time series regression. Biometrika, 75(2), 335-345.

Sansone, A., \& Justel, S. (2016). Exchange rate pass-through to prices: VAR evidence for Chile. Economia Chilena, 19(1), 20-37.

Sevüktekin, M. ve Çınar, M. (2017). Ekonometrik Zaman Serileri Analizi,Eviews Uygulamalı (5. b.). Bursa: Dora.

Takhtamanova, Y. F. (2010). Understanding changes in exchange rate pass-through. Journal of Macroeconomics, 32, 1118-1130.

Taylor, J. B. (2000). Low inflation, pass-through, and the pricing power of firms. European Economic Review, 44(7), 1389-1408.

Tümtürk, O. (2017). Türkiye'de döviz kurlarının yurtiçi fiyatlara geçiş etkisi ve enflasyon hedeflemesi. Yönetim ve Ekonomi: Celal Bayar Üniversitesi İktisadi ve Idari Bilimler Fakültesi Dergisi, 24(3), 837-855.

Türk, E. ve Çetinkaya, A. T. (2015). Döviz kurundan fiyatlara geçiş etkisinin Granger nedensellik testi ile incelenmesi "Türkiye örneği". Kırıkkale Üniversitesi Sosyal Bilimler Dergisi, 5(1), 27-38.

Zorzi, M. C., Hahn, E., \& Sánchez, M. (2007). Exchange rate pass-through in emerging markets. Frankfurt: European Central Bank (ECB) Working Paper No. 739. 